\title{
Exergy, Energy, and Dynamic Parameter Analysis of Indigenously Developed Low-Concentration Photovoltaic System
}

\author{
Pankaj Yadav, ${ }^{1}$ Brijesh Tripathi, ${ }^{1,2}$ and Manoj Kumar ${ }^{2}$ \\ ${ }^{1}$ School of Solar Energy, Pandit Deendayal Petroleum University, Gandhinagar 382007, India \\ ${ }^{2}$ School of Technology, Pandit Deendayal Petroleum University, Gandhinagar 382007, India \\ Correspondence should be addressed to Manoj Kumar; manoj.kspv@gmail.com
}

Received 29 May 2013; Revised 26 July 2013; Accepted 11 August 2013

Academic Editor: Mahmoud M. El-Nahass

Copyright ( $\odot 2013$ Pankaj Yadav et al. This is an open access article distributed under the Creative Commons Attribution License, which permits unrestricted use, distribution, and reproduction in any medium, provided the original work is properly cited.

Piecewise linear parabolic trough collector (PLPTC) is designed and developed to concentrate solar radiation on monocrystalline silicon based photovoltaic module. A theoretical model is used to perform electrical energy and exergy analysis of low-concentration photovoltaic (LCPV) system working under actual test conditions (ATC). The exergy efficiency of LCPV system is in the range from $5.1 \%$ to $4.82 \%$ with increasing rate of input exergy rate from $30.81 \mathrm{~W}$ to $96.12 \mathrm{~W}$, when concentration ratio changes from 1.85 to 5.17 Sun. Short-circuit current shows increasing trend with increasing input exergy rate of $\approx 0.011 \mathrm{~A} / \mathrm{W}$. Power conversion efficiency decreases from 7.07 to $5.66 \%$, and open-circuit voltage decreases from 9.86 to $8.24 \mathrm{~V}$ with temperature coefficient of voltage $\approx$ $-0.021 \mathrm{~V} / \mathrm{K}$ under ATC. The results confirm that the commercially available silicon solar PV module performs satisfactorily under low concentration.

\section{Introduction}

Silicon based solar photovoltaic (PV) technology is emerging as a potential renewable energy source for future power requirements. There are several ways by which the cost of this technology can be reduced, for example, improving the efficiency, efficient light trapping, using thinner wafer, thin-film silicon technology, concentrator photovoltaic (CPV) technology, and so forth. In CPV, compared to nonconcentrating solar PV systems, the required area for solar PV module is reduced by the factor of concentration ratio, providing significant reduction in the overall cost of solar PV system. The considerable amount of research is going on in the field of CPV systems with different optics (mirrors or lenses-Fresnel or anidolic), spot sizes and geometries, tracking strategies, cooling systems (active or passive), and cells ( $\mathrm{Si}$ or III-V compound semiconductors, whether single or multi-junction) $[1,2]$. Composite splitspectrum concentrator solar cell having efficiency of fortythree per cent has been reported at laboratory level [3]. The III-V compound based multi-junction solar cells are quite expensive [4], and for bringing them to commercial level, it needs a geometrical concentration ratio (CR) of greater than 500. Generally, the higher the concentration ratio, the greater the accuracy needed in tracking the Sun and the smaller the manufacturing and installation tolerances permitted. This means that high efficiency and high concentration concepts need very accurate systems, including their manufacture, installation, and Sun tracking which increases their cost.

In the beginning of this decade, Sala et al. [5] and Aminox Inc. [6] have shown that the efficiency of silicon based photovoltaic system increases with concentration ratio wherein they show that the optimum performance for silicon solar cells lies near to five Sun to extract maximum power. An industrialization potential of silicon based concentrator photovoltaic system with an estimated cost of $\$ 0.5 / W_{p}$ is reported by Castro et al. [7], where the group uses back contact solar cells under 100 Sun. A detailed review of modeling in relation to low-concentration solar concentrating photovoltaic is presented by Zahedi [8]. Li et al. have studied the performance of solar cell array based on a trough concentrating photovoltaic/thermal system [9]. Recently, Schuetz 
et al. [10] have reported design and construction of $\sim 7 \times$ low-concentration PV system based on compound parabolic concentrators.

Despite all these progresses of the LCPV system, this technology is unable to get market share among existing PV technologies, that is, monocrystalline $\mathrm{Si}$, flat panel, and thinfilm technologies. Low-concentration photovoltaic technology has been limited due to requirement of special solar cell design, perfect concentration geometry, and insufficient analysis of various issues such as exergy, thermalization losses, junction temperature, and recombination processes. To surmount such issues, in depth understanding of dependence of solar cell design parameters on CR and temperature, better design of concentration systems, and proper system performance evaluation is required. For LCPV systems, such important aspects have been scarcely addressed in detail so far, to the best of our knowledge.

Keeping in view the above-mentioned shortfalls, we have the (i) the design and development of linear piecewise parabolic trough for LCPV application and (ii) presented a theoretical model to perform exergy, energy, and dynamic behavior analysis of LCPV system. In this paper, actual climatic conditions are taken as reference state.

\section{Theoretical Modeling}

2.1. Design and Modeling of PLPTC. In this section, design of piecewise linear parabolic trough collector (PLPTC) is presented. The parabola is designed in such a way that maximum energy and exergy can be extracted from the LCPV system. A schematic diagram of PLPTC is shown in Figure 1. The design of PLPTC depends on receiver's geometry, acceptance angle subtended by the receiver with parabolic reflector, and desired geometric concentration.

The level of concentration is restricted by the design parameters, which include rim angle $\left(\emptyset_{r}\right)$, acceptance angle $\left(\theta_{c}\right)$, and effective entrance aperture area (width, $W \times$ length, $L)$. In this section, theoretical model of a PLPTC with geometrical CR $\sim 8$ Sun is presented [11].

The actual concentration ratio is calculated by

$$
\mathrm{CR}=180 *\left(\frac{\sin \emptyset_{r}-\sin \theta_{c} \cos \left(\emptyset_{r}-\theta_{c}\right)}{\pi\left(\emptyset_{r}+90-\theta_{c}\right) \sin \theta_{c}}\right) .
$$

The amount of light received by solar PV module depends on the reflectivity of mirrors used in the LCPV system.

The line of focus for PLPTC can be located using the following:

$$
F=\frac{W^{2}}{16 D}
$$

Using focal length and the depth of parabola, the rim angle is calculated from the following

$$
\cos \emptyset_{r}=\left(\frac{2 F}{\sqrt{(0.5 W)^{2}+(D-F)^{2}}}\right)-1 .
$$

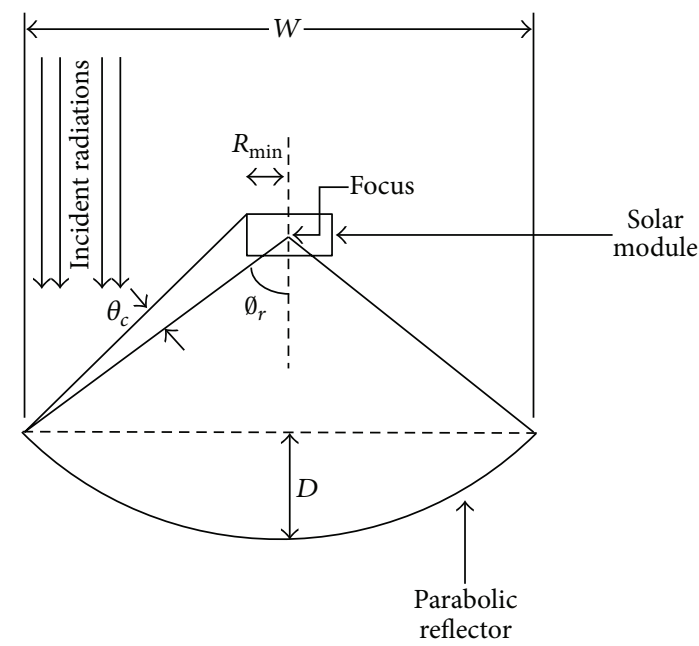

FIGURE 1: Basic geometry of parabolic trough concentrator.

For the condition of $F=D$ in (3), the rim angle becomes equal to $90^{\circ}$, and the receiver makes minimum intercept angle with radiation reflected from PLPTC. The relation between $R_{\min }$ and the acceptance angle is given by

$$
\sin \theta_{c}=\frac{R_{\min }\left(1+\cos \emptyset_{r}\right)}{2 F} .
$$

The receiver with the width of $R_{\min }$ (equal to $3.2 \mathrm{~cm}$ in this case) is able to intercept all the radiation coming with an angle $2 \emptyset_{r}$. From these equations, it is established that the CR can be changed by changing the effective aperture area of PLPTC. In developed PLPTC, the numbers of reflecting mirrors are varied from 2 to 8 to change the effective exit aperture area which gives desirable geometrical CR ( $\sim 2$ to 8 Sun).

2.2. Thermodynamic Analysis for Exergetic Calculations. The laws of thermodynamics are applied for the electrical exergy and energy analysis of LCPV system. Energy conservation and energy quantity are generally analyzed by using the first law of thermodynamics. Exergy analysis which deals with availability of energy in the system, nature of irreversibility, and quality of energy is presented using the second law of thermodynamics. Exergy measures not only quantity but also the quality of energy, which is not conserved but rather is in part destroyed or lost. Thermodynamic analysis for the electrical output of LCPV system is performed using the method described by many researchers [12-15].

The magnitude of the energy rate on the focal plane of PLPTC (where crystalline solar PV module is placed) can be expressed as [16]

$$
\dot{Q}_{f}=\pi f^{2}\left[\sin ^{2}\left(\phi_{\text {rim }}\right)-\sin ^{2}\left(\phi_{s}\right)\right] \rho_{\text {mirror }} G_{b},
$$

where $\rho_{\text {mirror }}$ represents the reflectivity of mirror, $\phi_{s}$ represents the shading angle, and $G_{b}$ represents direct beam solar radiation on parabola aperture. The energy rate, $\dot{Q}_{f}$, represents energy flow per unit time at which solar energy reaches the front glass of LCPV module. The energy received 
at front glass of LCPV module undergoes radiative and convective losses, which can be expressed in terms of heat loss coefficient, $U_{g}$ (measured in terms of $\mathrm{W} / \mathrm{K}$ ) [16],

$$
U_{g}=U_{\text {con }}+U_{\text {rad }}
$$

After considering these heat losses, the energy rate on the front glass of LCPV module, $\dot{Q}_{g}$, can be expressed as

$$
\dot{Q}_{g}=\dot{Q}_{f}-U_{g}\left(T_{g}-T_{\mathrm{amb}}\right) \text {. }
$$

Since the thickness of the glass is very small, the conduction heat loss coefficient could be ignored for further calculations. The incoming energy rate to LCPV module, $\dot{Q}_{\text {in }}$, is given as

$$
\dot{Q}_{\text {in }}=\dot{Q}_{g} \tau \text {, }
$$

where $\tau$ represents transmission coefficient of front glass of LCPV module.

The output energy rate of LCPV module, $\dot{Q}_{\text {out }}$, is calculated using the following expression [15]:

$$
\dot{Q}_{\text {out }}=\dot{Q}_{\mathrm{el}}+\dot{Q}_{\text {th }}=V_{\mathrm{OC}} I_{\mathrm{SC}}+\dot{Q}_{\mathrm{th}} \text {, }
$$

where $\dot{Q}_{\mathrm{el}}$ represents electrical output energy rate and $\dot{Q}_{\text {th }}$ represents thermal output energy rate, respectively. The energy efficiency of LCPV system can be defined as the ratio of output energy rate to the input energy rate. A detailed calculation of LCPV module's electrical power conversion efficiency starting with terminal equation is given in Section 2.3.

Similar expression for output exergy rate of LCPV system is given as [15]

$$
\dot{E} x_{\mathrm{out}}=\dot{E} x_{\mathrm{el}}+\dot{E} x_{\mathrm{th}}+\dot{E} x_{\mathrm{des}}
$$

where $\dot{E} x_{\mathrm{des}}=\dot{E} x_{\mathrm{des}, \mathrm{el}}+\dot{E} x_{\mathrm{des}, \mathrm{opt}}+\dot{E} x_{\mathrm{des}, \Delta T_{\mathrm{sun}}}+\dot{E} x_{\mathrm{des}, \Delta T_{\mathrm{mod}}}$, which includes electrical exergy destruction rate $\left(\dot{E} x_{\text {des,el }}\right)$ caused by series and shunt resistance losses [15], optical exergy destruction rate $\left(\dot{E} x_{\text {des,opt }}\right)$ caused by optical losses in LCPV module surface $[17,18]$, thermal exergy destruction rate $\left(\dot{E} x_{\text {des, } \Delta T_{\text {sun }}}\right)$ caused by temperature difference between LCPV module surface and the sun surface temperature [17$20]$, and thermal exergy destruction rate $\left(\dot{E} x_{\text {des, } \Delta T_{\text {mod }}}\right)$ caused by temperature variation of LCPV module with respect to reference environmental state $[19,20]$. The electrical exergy destruction rate is given as [15]

$$
\dot{E} x_{\text {des,el }}=V_{\mathrm{OC}} I_{\mathrm{SC}}-V_{\mathrm{mp}} I_{\mathrm{mp}} .
$$

In case of LCPV/T systems, thermal losses become thermal gain, which is not in the scope of this paper (which deals with only electrical energy and exergy analysis of LCPV system). Under this scenario, in (10), the term representing exergy destruction rate is insignificant compared with electrical exergy rate $\left(\dot{E} x_{\mathrm{el}}\right)$ and thermal exergy rate $\left(\dot{E} x_{\mathrm{th}}\right)$, so the effective expression for output exergy rate is given as [15]

$$
\begin{aligned}
\dot{E} x_{\mathrm{out}} & =\dot{E} x_{\mathrm{el}} \pm \dot{E} x_{\mathrm{th}} \\
& =V_{\mathrm{mp}} I_{\mathrm{mp}}-\left\{U_{g} A\left(T_{C}-T_{\mathrm{amb}}\right)\left(1-\frac{T_{\mathrm{amb}}}{T_{C}}\right)\right\}
\end{aligned}
$$

where the first term represents electrical exergy rate $\left(V_{\mathrm{mp}}\right.$ and $I_{\mathrm{mp}}$ being a voltage and current, resp., at maximum power point of LCPV module) and the second term represents thermal exergy rate due to the temperature difference between cell temperature and ambient temperature. The negative sign with the second term in (12) corresponds to the lost thermal exergy which would have been a gain in case of LCPV/T system with a positive sign. The input exergy includes solar radiation intensity exergy, which can be estimated by maximum efficiency ratio, $\psi$, given by Petala's theorem [16]:

$$
\psi=1+\frac{1}{3}\left(\frac{T_{\mathrm{amb}}}{T_{\text {sun }}}\right)^{4}-\frac{4}{3} \frac{T_{\mathrm{amb}}}{T_{\text {sun }}} .
$$

The input exergy rate to the PLPTC is found as [16]

$$
\dot{E} x_{\text {in }}=G_{b} A \psi \text {. }
$$

The exergy efficiency of LCPV system is defined as ratio of output exergy rate to the input exergy rate of the system [15]:

$$
\begin{aligned}
\eta_{\mathrm{ex}} & =\frac{\dot{E} x_{\mathrm{out}}}{\dot{E} x_{\mathrm{in}}} \\
& =\frac{V_{\mathrm{mp}} I_{\mathrm{mp}}-\left\{U_{g} A\left(T_{C}-T_{\mathrm{amb}}\right)\left(1-T_{\mathrm{amb}} / T_{C}\right)\right\}}{G_{b} A\left\{1+(1 / 3)\left(T_{\mathrm{amb}} / T_{\mathrm{sun}}\right)^{4}-(4 / 3)\left(T_{\mathrm{amb}} / T_{\mathrm{sun}}\right)\right\}} .
\end{aligned}
$$

2.3. Model for Electrical Energy Analysis. When a solar PV module is exposed to solar radiation, it shows nonlinear current-voltage characteristics. The output current-voltage characteristic of solar PV module is mainly influenced by the solar insolation and cell temperature. There exist many mathematical models used for computer simulation, which describe the effect of solar insolation and cell temperature on output current-voltage characteristics of solar PV module [21-23].

A crystalline silicon wafer-based solar photovoltaic (PV) cell of size $125 \mathrm{~mm} \times 125 \mathrm{~mm}$ typically produces around $2.5 \mathrm{~W}$ at a voltage of $560 \mathrm{mV}$. These cells are connected in series and/or parallel configuration on a module to produce required power. The equivalent circuit for solar PV module, having $N_{P}$ numbers of cells arranged in parallel and $N_{S}$ number of cells arranged in series, is shown in Figure 2.

The terminal equation for current and voltage of the solar PV array is mentioned as follows as described by other researchers [25-28]:

$$
\begin{aligned}
I= & N_{P} I_{\mathrm{PH}}-N_{P} I_{S}\left[\exp \left(\frac{q\left(V / N_{S}+I R_{S} / N_{P}\right)}{k_{B} T_{C} A}\right)-1\right] \\
& -\frac{\left(N_{P} V / N_{S}+I R_{S}\right)}{R_{\mathrm{SH}}} .
\end{aligned}
$$

Ideally, a solar PV module offers a low series resistance and high shunt resistance for higher solar energy conversion. In solar PV modules, the PV cells are generally connected in series in order to obtain adequate working voltage. The solar 


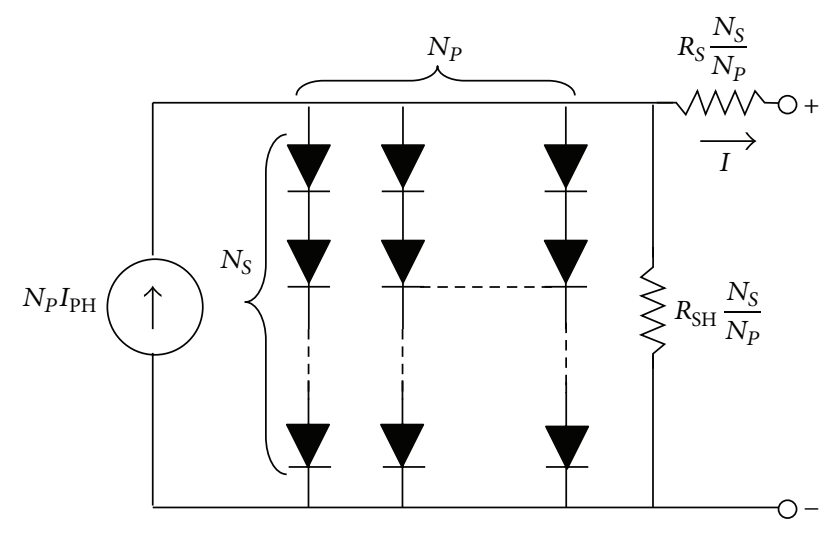

Figure 2: The general model for solar PV module.

PV modules can be arranged in series-parallel combination to make an array, which produces desired power. The currentvoltage characteristic of such array is described by (16). Generally, for the solar PV module $I_{\mathrm{PH}} \gg I_{S}$, in (16), the small diode and ground-leakage currents can be ignored under zero-terminal voltage. Therefore, the short-circuit current is approximately equal to the photocurrent. The expression for $I_{\mathrm{PH}}$ is given by

$$
I_{\mathrm{PH}}=\left[I_{\mathrm{SC}}+K_{I}\left(T_{C}-T_{\mathrm{Ref}}\right)\right] \lambda,
$$

where $\lambda=\rho_{\text {mirror }} \times \mathrm{CR} \times G_{b}$ in $\mathrm{W} / \mathrm{m}^{2}, \rho_{\text {mirror }}$ represents reflection coefficient of mirrors.

The photocurrent $\left(I_{\mathrm{PH}}\right)$ mainly depends on the solar insolation and cell's working temperature. The saturation current of a solar cell varies with the cell temperature, which is described by

$$
I_{S}=I_{\mathrm{RS}}\left(\frac{T_{C}}{T_{\mathrm{Ref}}}\right)^{3} \exp \left[\frac{q E_{g}\left(1 / T_{\mathrm{Ref}}-1 / T_{C}\right)}{k_{B} A}\right] .
$$

Reverse saturation current of the cell at reference temperature depends on the open-circuit voltage $\left(V_{\mathrm{OC}}\right)$ and can be approximately obtained by following equation as given by Tsai et al. [29]:

$$
I_{\mathrm{RS}}=\frac{I_{\mathrm{SC}}}{\left[\exp \left(q V_{\mathrm{OC}} / N_{S} k_{B} A T_{C}\right)-1\right]} .
$$

The maximum power output of LCPV module is related to the $I_{\mathrm{SC}}$ and $V_{\mathrm{OC}}$ by following:

$$
P_{\mathrm{MAX}}=\mathrm{FF} \times V_{\mathrm{OC}} \times I_{\mathrm{SC}} .
$$

The values of $I_{\mathrm{SC}}, V_{\mathrm{OC}}$, and FF can be determined from the $I-V$ characteristics obtained by (16). The electrical power conversion efficiency $(\eta)$ of LCPV module can be calculated by the ratio of maximum output power generated by LCPV module to the input power carried by solar radiation (i.e., $\eta=$ $\left.P_{\text {MAX }} / \lambda\right)$.

A solar PV module mainly consists of three types of resistance: series resistance $\left(R_{S}\right)$, shunt resistance $\left(R_{\mathrm{SH}}\right)$, and dynamic resistance $\left(r_{d}\right)$. The series resistance $R_{S}$ can be determined by various illumination conditions such as dark, constant illumination, and varying illumination, and they yield different results [30]. The output impedance of solar $\mathrm{PV}$ module, that is, dynamic resistance is usually composed of the series resistance and shunt resistance. In this paper, dynamic resistance of LCPV module is quantified by using direct estimation method reported by Wang et al. [31]. The equivalent circuit for solar PV module is shown in Figure 2.

In order to estimate the dynamic resistance which is defined as the negative reciprocal of $d I / d V$, (16) is differentiated with respect to $V$, that is,

$$
\begin{aligned}
\frac{d I}{d V}= & -\frac{N_{P}}{N_{S} R_{\mathrm{SH}}}-\frac{d I}{d V} \cdot \frac{R_{S}}{R_{\mathrm{SH}}} \\
& -\frac{N_{P} I_{S} q}{k T_{C} A}\left[\frac{1}{N_{S}}+\frac{d I}{d V} \cdot \frac{R_{S}}{N_{P}}\right] \\
& \times \exp \left[\frac{q}{k T_{C} A} \cdot\left(\frac{V}{N_{S}}+\frac{I R_{S}}{N_{P}}\right)\right] .
\end{aligned}
$$

For the open-circuit condition and short-circuit conditions of LCPV module, the following two expressions are given using the slope of one $I-V$ characteristics at the points $\left(V_{\mathrm{OC}}, 0\right)$ and $\left(0, I_{\mathrm{SC}}\right)$ by

$$
\begin{aligned}
& R_{s 0}=-\left(\left.\frac{d I}{d V}\right|_{V=V_{\mathrm{OC}}}\right)^{-1}, \\
& R_{\mathrm{sh} 0}=-\left(\left.\frac{d I}{d V}\right|_{I=I_{\mathrm{SC}}}\right)^{-1},
\end{aligned}
$$

respectively. When the load is disconnected from the LCPV module and the output current $(I)$ is equal to zero, (21) can be expressed by

$$
\begin{aligned}
\left.\frac{d I}{d V}\right|_{V=V_{\mathrm{OC}}}= & -\frac{N_{P}}{N_{S} R_{\mathrm{SH}}}-\left.\frac{d I}{d V}\right|_{V=V_{\mathrm{OC}}} \cdot \frac{R_{S}}{R_{\mathrm{SH}}} \\
& -\frac{N_{P} I_{S} q}{k T_{C} A}\left[\frac{1}{N_{S}}+\left.\frac{d I}{d V}\right|_{V=V_{\mathrm{OC}}} \cdot \frac{R_{S}}{N_{P}}\right] \\
& \times \exp \left[\frac{q}{k T_{C} A} \cdot \frac{V}{N_{S}}\right] .
\end{aligned}
$$

Equation (24) is further simplified to

$$
\begin{gathered}
-\left.\frac{1}{N_{P} I_{S}} \frac{k T_{C} A}{q} \frac{d I}{d V}\right|_{V=V_{\mathrm{OC}}} \exp \left[-\frac{q}{k T_{C} A} \cdot \frac{V_{\mathrm{OC}}}{N_{S}}\right] \\
\cong \frac{1}{N_{S}}+\left.\frac{d I}{d V}\right|_{V=V_{\mathrm{OC}}} \cdot \frac{R_{S}}{N_{P}} .
\end{gathered}
$$

Therefore, series resistance $R_{S}$ is expressed by

$$
R_{S}=\frac{R_{s 0} N_{P}}{N_{S}}-\frac{k T_{C} A}{q I_{S}} \exp \left[-\frac{q}{k T_{C} A} \cdot \frac{V_{\mathrm{OC}}}{N_{S}}\right]
$$


TABLE 1: Simulation parameters for desired CR in developed LCPV system.

\begin{tabular}{lccccccc}
\hline $\begin{array}{l}\text { Number of } \\
\text { mirrors }\end{array}$ & Width, $W(\mathrm{~m})$ & Rim angle $\left(\emptyset_{r}\right)$ & Acceptance angle $\left(\theta_{c}\right)$ & Length, $L(\mathrm{~m})$ & Effective $A_{a}\left(\mathrm{~m}^{2}\right)$ & $\mathrm{CR}$ & Solar radiation $\left(\mathrm{W} / \mathrm{m}^{2}\right)$ \\
\hline 2 mirrors & 0.27 & $13.51^{\circ}$ & $3.17^{\circ}$ & 0.30 & 0.054 & 1.85 & 1225 \\
4 mirrors & 0.45 & $25.02^{\circ}$ & $3.07^{\circ}$ & 0.30 & 0.108 & 3.56 & 2254 \\
6 mirrors & 0.62 & $33.78^{\circ}$ & $2.94^{\circ}$ & 0.30 & 0.159 & 4.72 & 3234 \\
8 mirrors & 0.79 & $41.98^{\circ}$ & $2.80^{\circ}$ & 0.30 & 0.211 & 5.17 & 3822 \\
\hline
\end{tabular}

For short-circuit condition, the output voltage of LCPV module is zero so (21) is reduced to

$$
\begin{aligned}
\left.\frac{d I}{d V}\right|_{I=I_{\mathrm{SC}}}= & -\frac{N_{P}}{N_{S} R_{\mathrm{SH}}}-\left.\frac{d I}{d V}\right|_{I=I_{\mathrm{SC}}} \cdot \frac{R_{S}}{R_{\mathrm{SH}}} \\
& -\frac{N_{P} I_{S} q}{k T_{C} A}\left[\frac{1}{N_{S}}+\left.\frac{d I}{d V}\right|_{I=I_{\mathrm{SC}}} \cdot \frac{R_{S}}{N_{P}}\right] \\
& \times \exp \left[\frac{q}{k T_{C} A} \cdot\left(\frac{I_{\mathrm{SC}} R_{S}}{N_{P}}\right)\right] .
\end{aligned}
$$

Equation (27) can be further simplified as

$$
\left.\frac{d I}{d V}\right|_{I=I_{\mathrm{SC}}}=-\frac{N_{P}}{N_{S} R_{\mathrm{SH}}}-\left.\frac{d I}{d V}\right|_{I=I_{\mathrm{SC}}} \cdot \frac{R_{S}}{R_{\mathrm{SH}}} .
$$

Therefore, the shunt resistance can be expressed by

$$
\begin{gathered}
R_{\mathrm{SH}}=-\frac{N_{S}}{N_{P}}\left(\left.\frac{d I}{d V}\right|_{I=I_{\mathrm{SC}}}\right)^{-1}, \\
R_{\mathrm{SH}}=\frac{N_{S}}{N_{P}} R_{\mathrm{sh} 0} .
\end{gathered}
$$

By analysis of (21), we conclude that the dynamic resistance of LCPV module is dependent on the solar irradiance and solar PV module temperature.

2.4. Statistical Analysis. To compare the theoretical and obtained experimental results, the correlation coefficient $(r)$ and root-mean square percent deviation $(e)$ have been evaluated by using the following expressions [32]:

$$
\begin{gathered}
r=\frac{N \sum X_{i} Y_{i}-\left(\sum X_{i} \sum Y_{i}\right)}{\sqrt{N \sum X_{i}^{2}-\left(\sum X_{i}\right)^{2}} \sqrt{N \sum Y_{i}^{2}-\left(\sum Y_{i}\right)^{2}}}, \\
e=\sqrt{\frac{\left(\sum e_{i}\right)^{2}}{N}},
\end{gathered}
$$

where $e_{i}=\left[\left(X_{i}-Y_{i}\right) / X_{i}\right] \times 100$. The variables $X_{i}$ and $Y_{i}$ represent theoretical and experimental data, respectively. The linear coefficient of correlation $(r)$, which ranges between -1 and 1 , measures strength and the direction of a linear relationship between two variables, that is, $X_{i}$ and $Y_{i}$. The $r$ value close to 1 indicates that two variables are in a strong positive linear correlation.

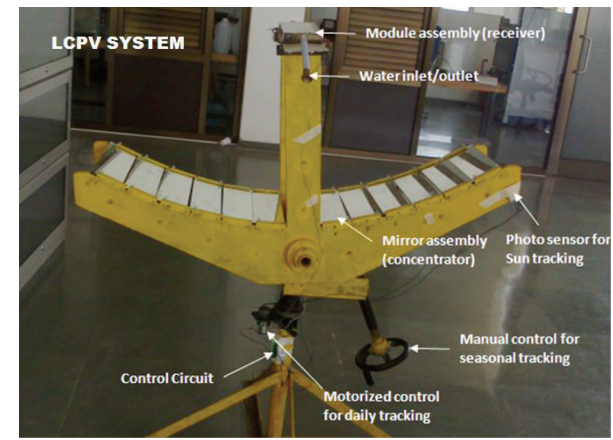

FIGURE 3: The constructed model of concentrator photovoltaic (CPV) system.

\section{LCPV Development and Validation of the Proposed Model}

3.1. System Development. A MATLAB/Simulink computer code is developed using the mathematical model discussed in Section 2 to simulate LCPV system. Table 1 shows the parameters used for calculating CR of the developed PLPTC. The CR depends on the effective aperture area which is governed by the number of mirrors used as reflectors. From Table 1, it is clear that by changing the number of mirrors from 2 to 8 , the geometric CR changes from $\sim 2$ to 8 Sun.

A piecewise linear parabolic LCPV system is developed as shown in Figure 3 by using the modeling parameters listed in Table 1. The effective aperture area available using 8 mirrors is $0.211 \mathrm{~m}^{2}$ and the effective receiver area is $0.027 \mathrm{~m}^{2}$, which gives the geometric concentration ratio of $\sim 8$. The receiver is made of a solar PV module fabricated by a string of sixteen commercially available silicon cell pieces (material: monocrystalline silicon, size: $14 \mathrm{~mm} \times 64 \mathrm{~mm}$, efficiency $\sim 14 \%$ ). The reason behind the selection of this specific size of the cells is to solve the current handling problem of the solar cells under concentration. A typical solar cell of size $125 \mathrm{~mm}$ $\times 125 \mathrm{~mm}$ producing $2.5 \mathrm{~W}$ at a voltage of $560 \mathrm{mV}$ would have a current handling capability of around $4.5 \mathrm{~A}$. This cell, when used under 10 Sun concentration may produce $45 \mathrm{~A}$ current by assuming a linear relationship between the current increment and CR. But if the size of the cell is reduced to $1 / 10$ th normal size, then the current generated under 10 Sun concentration would be less than or equal to $4.5 \mathrm{~A}$, then it will be easily handled without damaging the solar cell contacts. The incident solar radiation is reflected by PLPTC and concentrated on the focal plane having width of $0.64 \mathrm{~mm}$. 
TABLE 2: The parameters used for simulation under 1 Sun.

\begin{tabular}{lccccccccccccc}
\hline $\begin{array}{l}\text { Parameters } \\
\text { units }\end{array}$ & $R_{S}(\Omega)$ & $E_{g}(\mathrm{eV})$ & $N_{S}$ & $N_{P}$ & $A$ & $T_{\mathrm{C}}(\mathrm{K})$ & $T_{\mathrm{ref}}(\mathrm{K})$ & $k_{B}(\mathrm{~J} / \mathrm{K})$ & $K_{I}$ & $q(\mathrm{C})$ & $I_{\mathrm{SC}}(\mathrm{A})$ & $I_{\mathrm{RS}}(\mathrm{A})$ & $V_{\mathrm{OC}}(\mathrm{V})$ \\
\hline For 1 Sun & 0.071 & 1.12 & 16 & 1 & 1.5 & 298 & 298 & $1.38 \times 10^{-23}$ & $0.65 \times 10^{-3}$ & $1.602 \times 10^{-19}$ & 0.259 & $0.86 \times 10^{-12}$ & 9.86 \\
\hline
\end{tabular}

TABLE 3: The value of $R, C$, and corresponding $\tau$ obtained from the measured impedance spectra under different bias voltage conditions.

\begin{tabular}{lccc}
\hline $\begin{array}{l}\text { Applied } \\
\text { voltage } \\
(\mathrm{V})\end{array}$ & $\begin{array}{c}\text { Resistance in } \\
\text { equivalent circuit, } \\
R(\mathrm{k} \Omega)\end{array}$ & $\begin{array}{c}\text { Capacitance in } \\
\text { equivalent circuit, } \\
\mathrm{C}(\mathrm{nF})\end{array}$ & $\begin{array}{c}\text { Time } \\
\text { constant, } \tau \\
(\mathrm{ms})\end{array}$ \\
\hline-0.5 & 70 & 49 & 3.43 \\
-0.2 & 55 & 51.4 & 2.83 \\
0 & 45 & 36.2 & 1.63 \\
0.2 & 37 & 35.1 & 1.30 \\
0.5 & 28 & 32.1 & 0.90 \\
\hline
\end{tabular}

An active cooling mechanism is employed by flowing water behind the encapsulated solar PV module which is shown in Figure 3. By employing this mechanism, module temperature could be lowered down to $45^{\circ} \mathrm{C}$. A light dependent resistor (LDR) based one axis tracking system is developed for Sun tracking with a provision of manual tracking on second axis with an accuracy of $\pm 3^{\circ}$ as shown in Figure 3 .

\subsection{Theory Validation and Characterization of LCPV Module.}

The module characterization was done under standard test conditions (STC) by $I-V$ characteristics, impedance spectroscopy (IS), and capacitance-voltage (CV) measurement, and detailed parameters are given in Tables 2 and 3. The concentrated light is received by the solar PV module which is placed at the focal plane of the PLPTC. To simulate the electrical power generated from this PV module, the input parameters are series resistance, energy band gap, number of cells connected in series, number of strings connected parallel to each other, cell temperature, ambient temperature, shortcircuit current of module, open-circuit voltage of the module, and so on. These input parameters are listed in Table 2.

In this LCPV system, a solar PV module manufactured at WAAREE Energies Pvt. Ltd. module production line is used. The open-circuit voltage and short-circuit current of this module are measured as $V_{\mathrm{OC}}=9.86 \mathrm{~V}$ and $I_{\mathrm{SC}}=0.259 \mathrm{~A}$, respectively, under AM1.5 spectrum at 298.14 K. The currentvoltage output characteristics of generalized solar PV module under AM1.5 solar spectrum are shown in Figure 4. In the simulation, short-circuit current, open-circuit voltage, series resistance, and cell temperature measured under standard test conditions (STC) by manufacturer are taken as input parameters. The current-voltage characteristic generated from simulation program matches well with the experimental current-voltage characteristic.

Looking at the current-voltage curve, it can be identified that the photovoltaic module is a constant current source at lower values of voltage with current equal to the short-circuit current $\left(I_{\mathrm{SC}}\right)$. With the further increase in voltage values, the

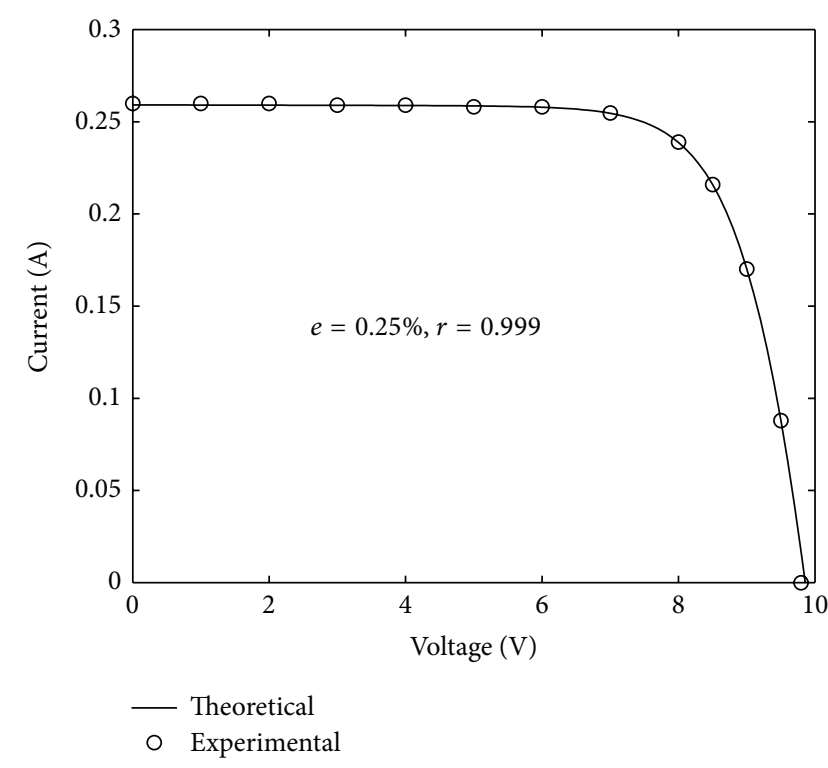

FIGURE 4: Current-voltage characteristics of the designed solar PV module under 1 Sun, AM1.5 at 298.14 K.

current starts decreasing exponentially at certain point. The value of current becomes zero at open-circuit voltage $\left(V_{\mathrm{OC}}\right)$. The point where the module operates at the highest efficiency is called maximum power point $\left(P_{\mathrm{MAX}}\right)$.

For impedance measurements, an ac signal having frequency in the range from $1 \mathrm{~Hz}$ to $0.1 \mathrm{MHz}$ with amplitude of $5 \mathrm{mV}$ is used. The impedance spectra were plotted in a complex plane (i.e., $Z^{\prime}$ versus $Z^{\prime \prime}$, also known as Nyquist or Cole-Cole plot [33]) which can provide information on any system that is composed of combination of interfacial and bulk process. The measurements were carried out on the developed LCPV module under forward and reverse bias $(+0.5 \mathrm{~V}$ to $-0.5 \mathrm{~V})$ conditions in the dark. Figure 5 shows the impedance spectrum of the LCPV module under reverse bias conditions (from 0 to $-0.5 \mathrm{~V}$ ). The radius of the semicircle increases with the increase in bias voltage as compared to zero bias demonstrating the bias dependence of resistance and capacitance [33]. The increase in the radius of semicircle during reverse bias is observed due to expansion of depletion region of the solar cell, which increases the resistance offered by the cell.

Figure 6 shows the impedance spectrum under the forward bias conditions (from 0 to $0.5 \mathrm{~V}$ ) where in contrast to the reverse bias, opposite behavior is observed. Here, the radius of the semicircle decreases with increasing positive bias from its maximum value at zero bias. The decrease in the radius of semicircle during forward bias is observed due to shrinking 


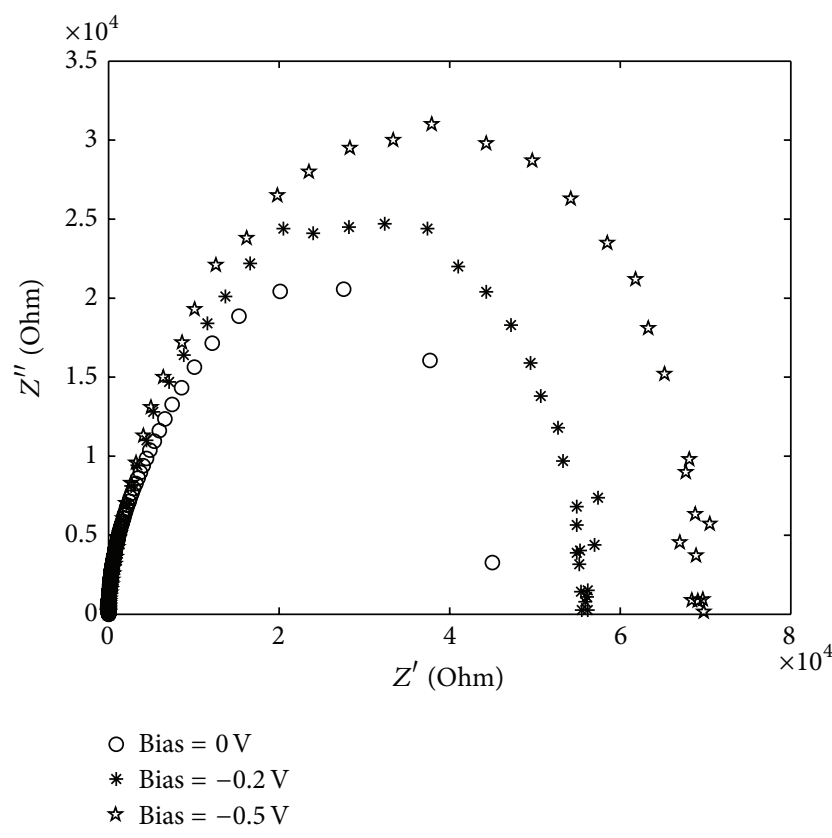

FIGURE 5: Impedance spectra of LCPV module under reverse bias conditions.

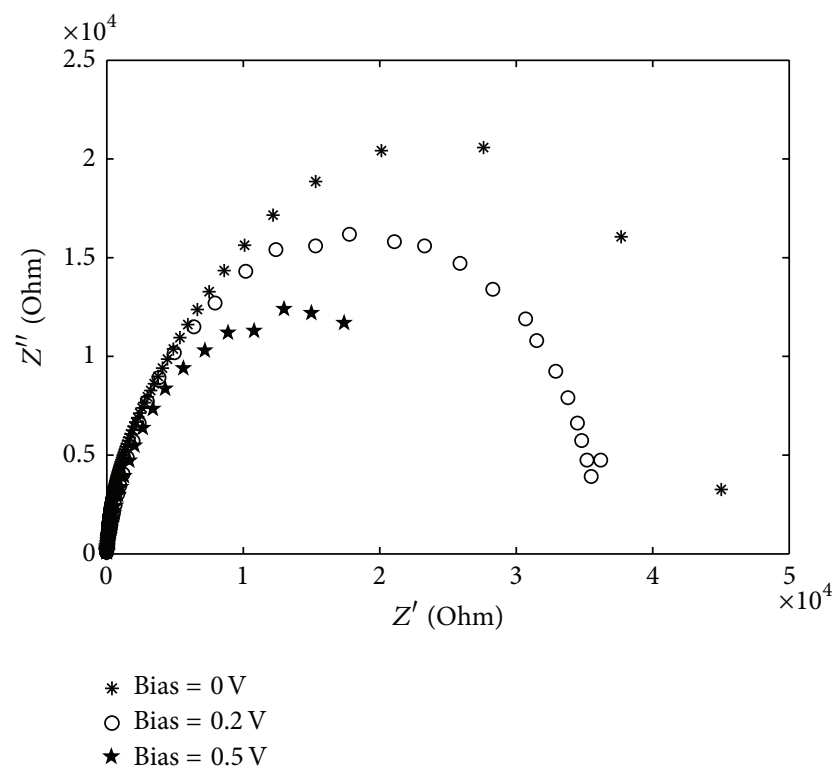

FIGURE 6: Impedance spectra of LCPV module under forward bias conditions.

of depletion region of the solar cell, which decreases the resistance offered by the cell.

The ac equivalent circuit of the $\mathrm{n}^{+}-\mathrm{p}-\mathrm{p}^{+}$structure under consideration is shown in Figure 7, which incorporates the capacitive effect owing to the excess minority carriers $\left(C_{d}\right.$ commonly known as the diffusion capacitance) in parallel with the depletion layer capacitance $C_{t}$ (Figure 7). Resistive effects arising from the minority carrier recombination are shown as the diffusion resistance $\left(R_{d}\right)$ in parallel with a shunt

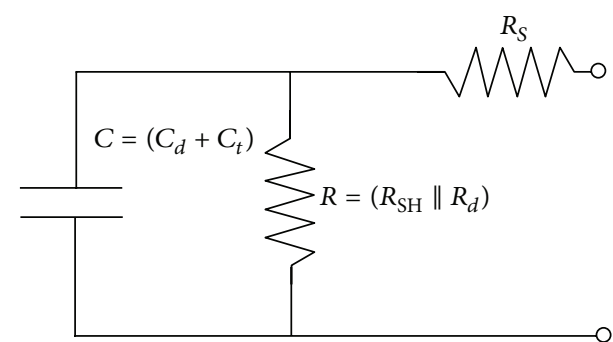

FIGURE 7: The ac equivalent circuit of LCPV module to explain observed impedance spectra.

$\left(R_{\mathrm{SH}}\right)$ resistance and a series resistance, $R_{S}$, connected in the circuit [33].

Under forward bias condition, due to the accumulation of minority carriers in the bulk, the magnitude of the diffusion capacitance is large compared to the depletion region capacitance [34]. The ac impedance of the circuit is given by

$$
Z(\omega)=Z^{\prime}(\omega)-j Z^{\prime \prime}(\omega)
$$

where $Z^{\prime}$ and $Z^{\prime \prime}$ are the magnitudes of the real and imaginary parts of impedance, and a minus sign arises due to capacitive reactance involved in the circuit. On analyzing the circuit, $Z^{\prime}$ and $Z^{\prime \prime}$ can be written as

$$
\begin{gathered}
Z^{\prime}(\omega)=R s+\frac{R}{1+(\omega R C)^{2}}, \\
Z^{\prime \prime}(\omega)=\frac{\omega C R^{2}}{1+(\omega R C)^{2}} .
\end{gathered}
$$

For the case of very low $R_{S}$, when $Z^{\prime}$ and $Z^{\prime \prime}$ are plotted in a complex plane, by varying the frequency $(\omega)$, a semicircle of radius $R / 2$ with its center at $(R / 2,0)$ is obtained. Further, because of the semicircular geometry, the maximum value of $Z^{\prime \prime}$ arises when $\omega_{m} R C=1$, where $\omega_{m}$ is the frequency at which $Z^{\prime \prime}$ becomes maximum. Thus, we have that $C=$ $1 / \omega_{m} R$, and the presence of $R_{S}$ shifts the semicircle, by its value, on the $x$-axis. The analysis of the impedance diagram on the complex plane, therefore, gives values of all the three parameters, that is, $R, C$, and $R_{S}$, used in the equivalent circuit. The product of resistance and capacitance $(R C)$ represents the time constant $(\tau)$. The value of $R, C$, and corresponding $\tau$ obtained from the measured impedance spectra under different bias voltage conditions is listed in Table 3 . These values are in good agreement with the existing literature for silicon solar cells [33, 35].

Capacitance-voltage $(C-V)$ measurement is an important tool to understand the transient behavior of a semiconductor device. Generally, capacitance is measured in the reversed bias (Mott-Schottky) condition to determine barrier potential and effective doping concentration. Capacitance-voltage characterization is done for the developed LCPV module as shown in Figure 8. 


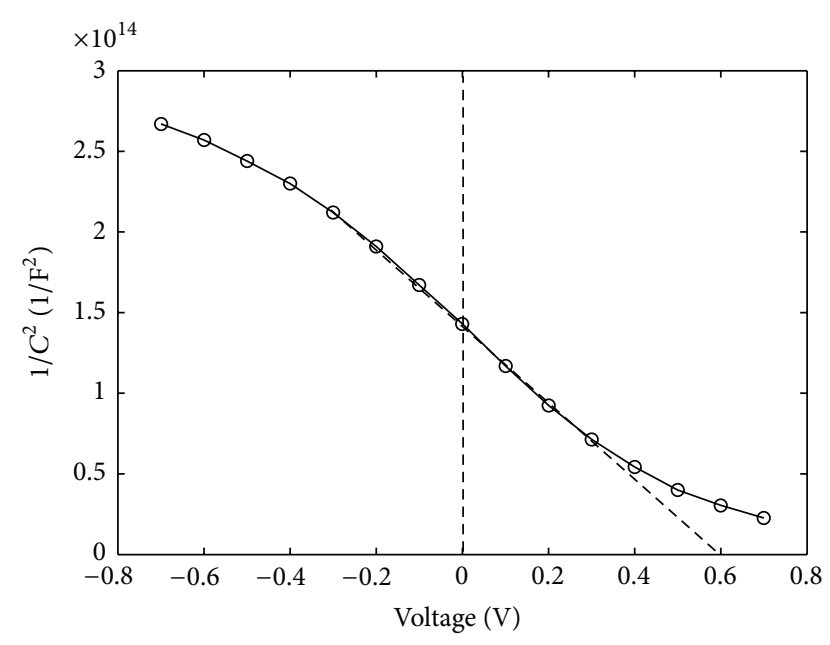

FIGURE 8: The capacitance-voltage characterization of LCPV module.

The dependence of barrier potential and doping concentration on the depletion region capacitance per unit area is given by [30]

$$
\begin{gathered}
\frac{1}{C^{2}}=\frac{2}{q K \varepsilon_{0} N}\left(V_{\mathrm{bi}}-V-\frac{2 k_{B} T}{q}\right), \\
\frac{d\left(1 / C^{2}\right)}{d V}=-\frac{2}{q K \varepsilon_{0} N},
\end{gathered}
$$

where $q$ is the electron charge, $K$ is dielectric constant of silicon, $\varepsilon_{0}$ is the permittivity of free space, $V_{\mathrm{bi}}$ is barrier potential, $k_{B}$ is Boltzmann's constant, $T$ is equal to $298.14 \mathrm{~K}, N$ is doping concentration, and $V$ represents applied potential.

The slope and its intersection on the abscissa in the MottSchottky plot shown in Figure 8 for the LCPV module gives the doping concentration $(N)$ and barrier potential $\left(V_{\mathrm{bi}}\right)$, respectively. The $N$ value is found as $7.79 \times 10^{16} \mathrm{~cm}^{-3}$, and the value of $V_{\mathrm{bi}}-2 \mathrm{kT} / \mathrm{q}$ is equal to $0.56 \mathrm{eV}$, which corresponds to $V_{\mathrm{bi}}=0.61 \mathrm{eV}$. The calculated values are in good agreement with the reported values for commercially available silicon solar cells $[36,37]$.

\section{LCPV Experiment under ATC}

The experiments were carried out in the campus of School of Solar Energy located in Gandhinagar, India (Lat: 23.22, Long: 72.68E), in the month of December (Year: 2012). The module temperature was measured with the digital thermometer having an accuracy of $\pm 0.1^{\circ} \mathrm{C}$ during experiments; wind speed was measured by anemometer as $0.85 \mathrm{~m} / \mathrm{s}$ with an accuracy of $\pm 5 \%$. Solar radiation and ambient temperature were recorded at the weather station located in the university campus. The following parameters were measured during experiments: ambient temperature, solar radiation, LCPV module and ambient temperature, load current, load voltage, short-circuit current, and open-circuit voltage. During the experiments, the module temperature was varied in the range of $300-350 \mathrm{~K}$ by controlling the flow rate of water behind the LCPV module. Since the aim of this paper is to extract maximum electrical output from LCPV systems, the thermodynamic analysis of flowing water is avoided here. The current-voltage measurements of an LCPV system are taken by Agilent SMU 6632B and by using multimeters and load rheostat. The sensitivity of the current-voltage measurement instrument is given as $\pm 3 \%$. The developed LCPV system is studied by varying the number of reflecting mirrors arranged in PLPTC.

\section{Result and Discussion}

5.1. Exergy and Energy Analysis. The effect of the light concentration and module temperature on the input exergy rate, electrical exergy output rate, and thermal exergy output rate of LCPV module is estimated from the proposed model in Section 2. It is found that with the increase in CR, the input exergy rate increases which results in increased amount of energy available to do useful work by the system. The data listed in Table 4 shows that the exergy efficiency decreases with the increase in the input exergy rate. This decrease is mainly due to the increase in cell temperature, which results in electrical exergy destruction with a rate of " $V_{\mathrm{OC}} I_{\mathrm{SC}}-$ $V_{\mathrm{mp}} I_{\mathrm{mp}}$ " [38]. Further, the increase in the cell temperature affects $V_{\mathrm{OC}}$ with a negative temperature coefficient as shown in the Figure 9. Figure 9 shows that $V_{\mathrm{OC}}$ decreases from $8.48 \mathrm{~V}$ to $8.24 \mathrm{~V}$ with increase in input exergy rate from $30.81 \mathrm{~W}$ to $96.12 \mathrm{~W}$, when the cell temperature changes from $321 \mathrm{~K}$ to $332.5 \mathrm{~K}$. The influence of the cell temperature on exergy efficiency is clearly observed (Table 4), which decreases with the increase in the cell temperature. Similar effect is observed by other researchers $[15,38]$. Since the cell temperature changes with the increase in the input exergy rate, it is imperative to design the LCPV system based on this information, so that useful exergy can be maximized. For this purpose, it is very important to track maximum power point, which depends on dynamic resistance of LCPV system.

The proposed model in Section 2 is used to perform energy analysis of the LCPV module having 16 cells connected in series. The static parameters $\left(I_{\mathrm{SC}}, V_{\mathrm{OC}}, P_{\mathrm{MAX}}\right.$, and $R_{S}$ ) of the LCPV module are measured in ATC conditions as well as calculated by the proposed theoretical model. The measured and simulated current-voltage characteristics of LCPV module is shown in Figure 9 with varying input energy rate and corresponding temperature.

It can be seen from Figure 9 that there is good agreement between the experimental and theoretical current-voltage characteristics, which include $I_{\mathrm{SC}}, V_{\mathrm{OC}}, P_{\mathrm{MAX}}, R_{S}, \mathrm{FF}, r_{d}$, and efficiency. The mean square of percentage deviation $(e)$ is in the range of $2.74-8.43 \%$ and the linear coefficient of correlation $(r)$ is in the range of $0.995-0.999$.

The measured values of solar irradiation, $I_{\mathrm{SC}}, V_{\mathrm{OC}}, P_{\mathrm{MAX}}$, $R_{S}$, temperature, FF, $r_{d}$, and efficiency are listed in Table 5. Generally, the output current of the solar PV modules increases with the increase in input energy rate (i.e., solar irradiance received at focal point of PLPTC). With increase in the solar irradiance, the higher number of photons strikes 
TABLE 4: Exergy analysis of LCPV system.

\begin{tabular}{lccccc}
\hline $\begin{array}{l}\text { Solar irradiation } \\
\left(\mathrm{W} / \mathrm{m}^{2}\right)\end{array}$ & Cell temperature, $T_{C}(\mathrm{~K})$ & Input exergy rate $(\mathrm{W})$ & \multicolumn{2}{c}{ Output exergy rate $(\mathrm{W})$} \\
Electrical & $\begin{array}{c}\text { Thermal exergy } \\
\text { rate }(\mathrm{W})\end{array}$ & Exergy efficiency, $\eta_{\text {ex }}(\%)$ \\
\hline 1225 & 321 & 30.81 & 2 & 0.43 & 5.10 \\
2254 & 328 & 56.68 & 3.55 & 0.70 & 5.03 \\
3234 & 331 & 81.33 & 4.91 & 0.83 & 5.01 \\
3822 & 332.5 & 96.12 & 5.54 & 0.91 & 4.82 \\
\hline
\end{tabular}

TABLE 5: Parameter estimated from $I-V$ curves plotted under various CR.

\begin{tabular}{lcccccccc}
\hline $\begin{array}{l}\text { Solar } \\
\text { irradiation } \\
\left(\mathrm{W} / \mathrm{m}^{2}\right)\end{array}$ & $\begin{array}{c}\text { Cell } \\
\text { temperature, } \\
T_{\mathrm{C}}(\mathrm{K})\end{array}$ & $\begin{array}{c}\text { Short-circuit } \\
\text { current, } I_{\mathrm{SC}}\end{array}$ & $\begin{array}{c}\text { Series } \\
\text { resistance, } R_{S}\end{array}$ & $\begin{array}{c}\text { Dynamic } \\
\text { resistance, } r_{d} \\
(\Omega)\end{array}$ & $\begin{array}{c}\text { Open-circuit } \\
\text { voltage, } V_{\mathrm{OC}} \\
(\mathrm{V})\end{array}$ & $\begin{array}{c}\text { Maximum } \\
\text { power, } P_{\mathrm{MAX}} \\
(\mathrm{W})\end{array}$ & $\begin{array}{c}\text { Fill factor, FF } \\
(\%)\end{array}$ & $\begin{array}{c}\text { Energy } \\
\text { efficiency, } \eta \\
(\%)\end{array}$ \\
\hline 1000 & 298 & 0.25 & 1.12 & 17.99 & 9.86 & 1.91 & 74.58 & 7.07 \\
1225 & 321 & 0.33 & 1.20 & 19.23 & 8.48 & 2.07 & 73.97 & 6.26 \\
2254 & 328 & 0.63 & 1.29 & 20.73 & 8.39 & 3.72 & 70.37 & 6.11 \\
3234 & 331 & 0.91 & 1.39 & 22.27 & 8.31 & 5.00 & 67.00 & 5.73 \\
3822 & 332.5 & 1.07 & 1.55 & 24.84 & 8.24 & 5.84 & 66.23 & 5.66 \\
\hline
\end{tabular}

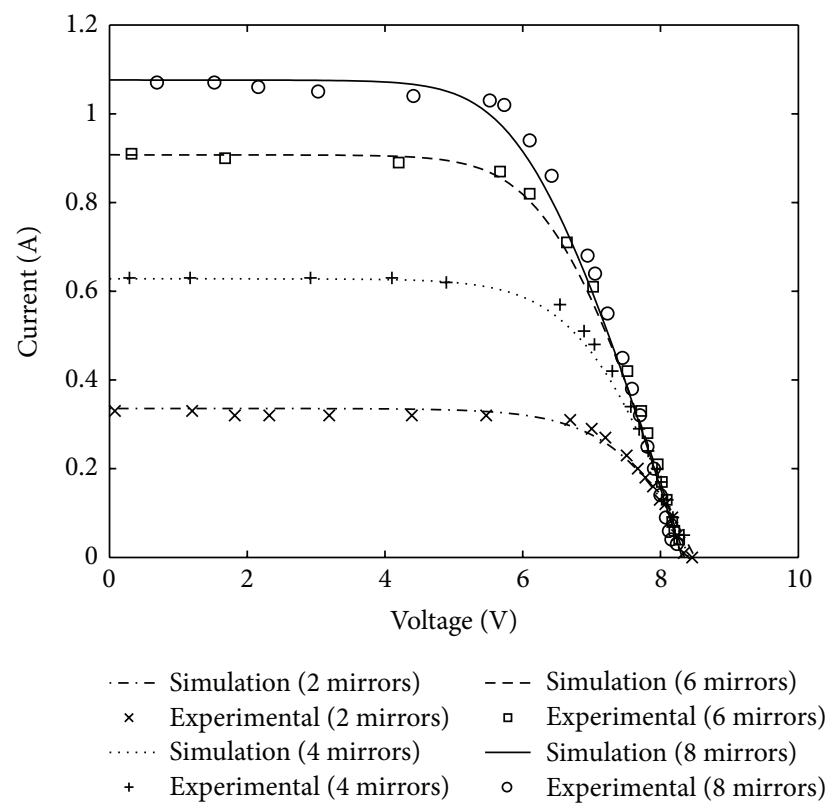

FIGURE 9: Simulated and experimental $I-V$ characteristics of LCPV system under ATC.

the solar PV module which results in enhanced electron-hole pair production and higher photocurrent [39]. The values of the dynamic resistance at MPP are computed using the values of $I_{\mathrm{PH}}, I_{\mathrm{SC}}$, and $R_{S}$. The dynamic resistance of LCPV module is calculated in an effective manner using (21) and is listed in Table 5. Approximate error between experimental and theoretical dynamic resistance of the LCPV module is found as $\sim 1.3 \%-2.1 \%$, which shows the uncertainty is well within the practically acceptable limits.

The plot shown in Figure 9 and extracted data listed in Table 5 describe the dependence of FF and efficiency of LCPV module on the change in input energy rate and module temperature. From the observed results, it can be concluded that the FF and efficiency of LCPV module decrease as the input energy rate increases. The decrease in FF and efficiency of solar PV module with the increasing energy rate is highly dependent on the increase in electrical exergy destruction of LCPV module due to the increase in input energy rate and temperature. As a result of increased input energy rate, dynamic resistance offers greater resistive power losses in LCPV module and thus reduces its performance by reducing the FF and efficiency. The increase in the dynamic resistance and reduction in the FF of LCPV module are foremost parameters for the decrease in the electrical energy efficiency.

The effects of the cell temperature $\left(T_{C}\right)$ on $I-V$ curve of LCPV module is estimated from the proposed model as shown in Figure 10. As the device temperature increases, small increase in short-circuit current is observed; however, the open-circuit voltage rapidly decreases due to the exponential dependence of the saturation current on the temperature as given by (18) [39]. In the actual experiments, similar effect of temperature on open-circuit voltage $\left(V_{\mathrm{OC}}\right)$ is observed, and it is found that the $V_{\mathrm{OC}}$ decreases from 9.86 to $8.24 \mathrm{~V}$ with temperature coefficient of voltage $\approx-0.021 \mathrm{~V} / \mathrm{K}$ under ATC as shown in Figure 9.

A decrease in the $P_{\mathrm{MAX}}$ with the increase in $T_{C}$ is observed because with the increase in temperature, the band gap of the intrinsic semiconductor shrinks. The increased temperature causes reduction in open-circuit voltage $\left(V_{\mathrm{OC}}\right)$ and the increase in the photocurrent for a given irradiance because of high injection of electrons from valance band to conduction band of semiconductor material [39].

5.2. Economical Analysis of LCPV System. Net Present Value (NPV) method allows analyzing the economic aspects of any engineering system and is used for the economic analysis of 
TABLE 6: Cost of various components of LCPV system $\left(\approx 1 \mathrm{~kW}_{\mathrm{P}}\right)$ to find initial investment cost (numbers provided here are in accordance with the current market price) $)^{*}$.

\begin{tabular}{|c|c|c|c|c|c|c|}
\hline \multirow{2}{*}{ Components } & \multirow{2}{*}{ Module } & \multicolumn{5}{|c|}{ BOS } \\
\hline & & Battery & Charge controller & Support structure & Tracker & Cabling \\
\hline Cost (in US\$) & 206 & 800 & 48 & 320 & 590 & 120 \\
\hline \multicolumn{6}{|c|}{ Total initial investment cost (in US\$) } & 2084 \\
\hline
\end{tabular}

${ }^{*}$ The price is based on market survey, which may vary depending on specific location or company.

TABLE 7: Economical analysis of LCPV system (having a lifetime of 25 years [24]).

\begin{tabular}{lccccccccc}
\hline Period (year) & 0 & 1 & 2 & 3 & 4 & 5 & 6 & 7 & 8 \\
\hline Initial investment cost & -2084 & & & & & & & \\
Benefits** & & 290.43 & 290.43 & 290.43 & 290.43 & 290.43 & 290.43 & 290.43 & 290.43 \\
O and M cost*** & & -2.18 & -2.30 & -2.43 & -2.57 & -2.72 & -2.88 & -3.04 & -3.21 \\
Discount rate & 0.01 & 0.01 & 0.01 & 0.01 & 0.01 & 0.01 & 0.01 & 0.01 & 0.01 \\
Net cash flow & & 288.25 & 288.13 & 287.995 & 287.86 & 287.71 & 287.55 & 287.39 & 287.21 \\
a & 0.99 & 0.99 & 0.98 & 0.97 & 0.96 & 0.95 & 0.94 & 0.93 & 0.92 \\
Discounted net cash flow & & 285.39 & 282.45 & 279.53 & 276.62 & 273.74 & 270.89 & 268.05 & 265.24 \\
NPV & & -1798.6 & -1516.2 & -1236.6 & -960 & -686.26 & -415.37 & -147.32 & 117.92 \\
\hline
\end{tabular}

** Benefits are based on the tariff policy of Gujarat Electricity Regulatory Commission released for projects commissioned in 2012 [24].

*** Escalation in operating cost is taken as $5.72 \%$ annually [24].

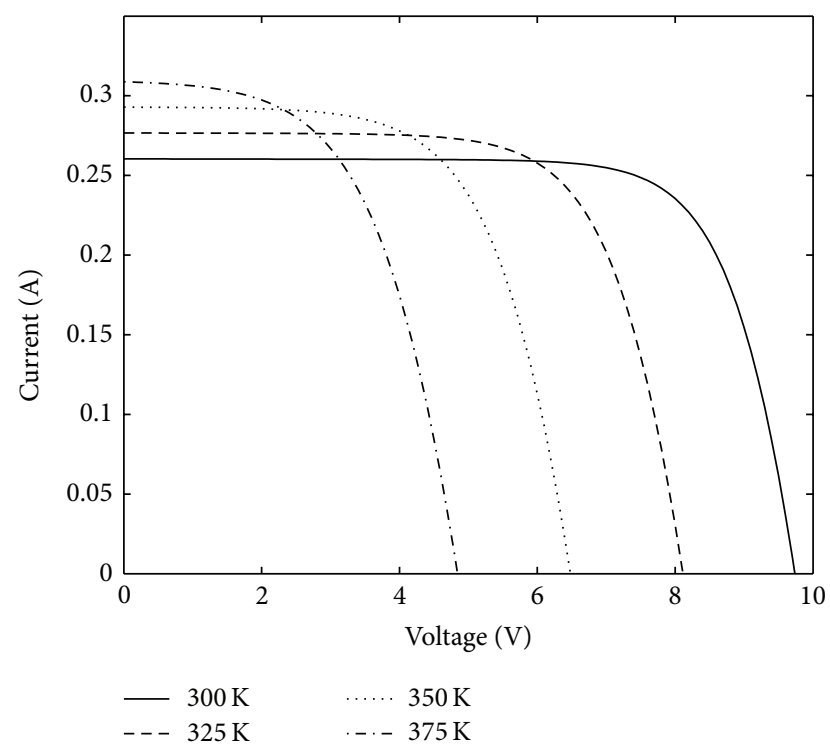

FIGURE 10: Variation of current-voltage characteristics with the cell temperature $T_{C}$.

developed LCPV system of $1 \mathrm{~kW}$. As the system presented in this paper is very small for economic analysis, the calculations are done for $1 \mathrm{~kW}_{\mathrm{P}}$ system. NPV method allows accounting for the present value of annual capital expenditures and savings during the lifetime of the system. Net present value (NPV) includes sum of all the current values (costs are shown as negative, and net savings are shown as positive). For acceptance of any engineering project, the positive NPV is desired. The formulas for calculating NPV and corresponding factor are given as [16]

$$
\begin{aligned}
\mathrm{NPV} & =\sum_{i=1}^{n}(B-C)_{i}, \\
a & =\frac{1}{(1+i)^{p}}
\end{aligned}
$$

where " $a$ " represents net present value factor, " $B$ " represents gain, " $p$ " represents the period, and " $i$ ” represents discount rate in the equation given previously.

The initial investment cost is required in order to calculate $\mathrm{NPV}$, which includes module cost and balance of systems (BOS) cost. The components of BOS include battery storage, charge controllers, support structure, tracking system, and transmission cables. Cost of all these components is listed in Table 6. Using the initial investment cost and the formula outlined in (34), the NPV is calculated (Table 7). Operation and maintenance $(\mathrm{O}$ and $\mathrm{M})$ cost is taken as $0.75 \%$ of the total investment cost with escalation in operating cost as $5.72 \%$ per annum [24]. The feasibility of this project is demonstrated by a positive value of NPV obtained within 8 years.

\section{Conclusions}

A theoretical model is used to perform electrical energy and exergy analyses of low-concentration photovoltaic (LCPV) system working under actual test conditions (ATC). The exergy efficiency of LCPV system is in the range from $5.1 \%$ to $4.82 \%$ with increasing rate of input exergy rate from $30.81 \mathrm{~W}$ to $96.12 \mathrm{~W}$, when concentration ratio changes 
from 1.85 to 5.17 Sun. Short-circuit current shows increasing trend with increasing input exergy rate of $\approx 0.011 \mathrm{~A} / \mathrm{W}$. Power conversion efficiency decreases from 7.07 to $5.66 \%$ and opencircuit voltage decreases from 9.86 to $8.24 \mathrm{~V}$ with temperature coefficient of voltage $\approx-0.021 \mathrm{~V} / \mathrm{K}$ under ATC. The results confirm that the commercially available silicon solar PV module performs satisfactorily under low concentration.

\section{Nomenclature}

CR: Concentration ratio

$W$ : Width of the profile

$D$ : Depth of the profile

$\emptyset_{r}$ : Rim angle

$\theta_{c}: \quad$ Acceptance angle

$F: \quad$ Focus point

$\rho_{\text {mirror }}$ : Reflectivity of mirrors

$R_{\min }$ : Half width of the solar panel

L: $\quad$ Parabolic trough length

$\alpha$ : Absorption coefficient

$A_{a}: \quad$ Aperture area

$k_{B}$ : Boltzmann's constant $\left(1.38 \times 10^{-23}\right)$

$I_{\mathrm{PH}}: \quad$ Light generated current

$I_{S}: \quad$ Cell saturation or dark current

$q$ : $\quad$ Electron charge $\left(1.6 \times 10^{-19} \mathrm{C}\right)$

A: $\quad$ Ideality factor

$U_{\text {rad }}$ Radiative heat loss coefficient

$U_{\text {con }}$ : Convective heat loss coefficient

$T_{C}$ : Working temperature of solar cell (Kelvin)

$R_{\mathrm{SH}}: \quad$ Shunt resistance

$R_{S}$ : $\quad$ Series resistance

$N_{S}$ : $\quad$ Series number of cells in a PV module

$N_{P}$ : Parallel number of modules for a PV array

$I_{\text {SC }}$ : Cell's short-circuit current at $298.14 \mathrm{~K}$ and $1 \mathrm{~kW} / \mathrm{m}^{2}$

$K_{I}$ : Cell's short-circuit current temperature coefficient

$T_{\text {Ref: }}$ Cell's reference temperature

$\lambda: \quad$ Solar insolation in $\mathrm{kW} / \mathrm{m}^{2}$

$I_{\mathrm{RS}}$ : Cell's reverse saturation current at a reference temperature and solar radiation

$E_{g}: \quad$ Band gap energy of the semiconductor

$I_{\mathrm{mp}}: \quad$ Current at maximum power point

$V_{\mathrm{mp}}$ : Voltage at maximum power point.

\section{Acknowledgments}

The authors acknowledge the financial support provided by Gujarat Energy Development Agency (GEDA) to develop CPV system by Grant no. GEDA/EC:REC/March2010/3/9174. Authors also acknowledge WAAREE Energies Pvt., Ltd., India, for providing encapsulated crystalline silicon solar PV modules for this study.

\section{References}

[1] G. Sala, D. Pachon, I. Anton, and Test, Test, Rating and Specification of PV Concentrator Components and Systems
(C-Rating Project). Bookl. Classification of PV Concentrators, Universidad Politecnica de Madrid, Madrid, Spain, 2002, http://www.ies-def.upm.es/ies/CRATING/Documents.htm.

[2] M. Yamaguchi and A. Luque, "High efficiency and high concentration in photovoltaics," IEEE Transactions on Electron Devices, vol. 46, no. 10, pp. 2139-2144, 1999.

[3] M. A. Green and A. Ho-Baillie, "Forty three per cent composite split-spectrum concentrator solar cell efficiency," Progress in Photovoltaics, vol. 18, no. 1, pp. 42-47, 2010.

[4] H. Cotal, C. Fetzer, J. Boisvert et al., "III-V multijunction solar cells for concentrating photovoltaics," Energy and Environmental Science, vol. 2, no. 2, pp. 174-192, 2009.

[5] G. Sala, I. Anton, J. Monedero et al., "The euclides-thermie concentrator power plant in continuous operation," in Proceedings of the 17th European Photovoltaic Solar Energy Conference (EUPVSEC '01), pp. 488-491, Munich, Germany, 2001.

[6] V. Garboushian, S. Yoon, G. Turner, A. Gunn, and D. Fair, "Novel high-concentration PV technology for cost competitive utility bulk power generation," in Proceedings of the 24th IEEE Photovoltaic Specialists Conference. Part 2 (of 2), pp. 1060-1063, December 1994.

[7] M. Castro, I. Anton, and G. Sala, "Pilot production of concentrator silicon solar cells: approaching industrialization," Solar Energy Materials and Solar Cells, vol. 92, no. 12, pp. 1697-1705, 2008.

[8] A. Zahedi, "Review of modelling details in relation to lowconcentration solar concentrating photovoltaic," Renewable and Sustainable Energy Reviews, vol. 15, no. 3, pp. 1609-1614, 2011.

[9] M. Li, X. Ji, G. Li, S. Wei, Y. Li, and F. Shi, "Performance study of solar cell arrays based on a trough concentrating photovoltaic/thermal system," Applied Energy, vol. 88, no. 9, pp. 3218-3227, 2011.

[10] M. A. Schuetz, K. A. Shell, S. A. Brown, G. S. Reinbolt, R. H. French, and R. J. Davis, "Design and construction of a $7 \times$ low-concentration photovoltaic system based on compound parabolic concentrators," IEEE Journal of Photovoltaics, vol. 2, no. 3, pp. 382-386, 2012.

[11] H. G. Riveros and A. I. Oliva, "Graphical analysis of sun concentrating collectors," Solar Energy, vol. 36, no. 4, pp. 313322, 1986.

[12] O. A. Jaramillo, J. A. Del Río, and G. Huelsz, “Thermal study of optical fibres transmitting concentrated solar energy," Journal of Physics D, vol. 32, no. 9, pp. 1000-1005, 1999.

[13] O. A. Jaramillo, G. Huelsz, and J. A. Del Río, "A theoretical and experimental thermal study of $\mathrm{SiO}_{2}$ optical fibres transmitting concentrated radiative energy," Journal of Physics D, vol. 35, no. 2, pp. 95-102, 2002.

[14] C. Kandilli and K. Ulgen, "Review and modelling the systems of transmission concentrated solar energy via optical fibres," Renewable and Sustainable Energy Reviews, vol. 13, no. 1, pp. 6784, 2009.

[15] A. S. Joshi, I. Dincer, and B. V. Reddy, "Thermodynamic assessment of photovoltaic systems," Solar Energy, vol. 83, no. 8, pp. 1139-1149, 2009.

[16] C. Kandilli, "Performance analysis of novel concentrating solar photovoltaic combined system," Energy Conversion and Management, vol. 67, pp. 186-196, 2013.

[17] K. Altfeld, W. Leiner, and M. Fiebig, "Second law optimization of flat-plate solar air heaters Part I: the concept of net exergy flow and the modeling of solar air heaters," Solar Energy, vol. 41, no. 2, pp. 127-132, 1988. 
[18] K. Altfeld, W. Leiner, and M. Fiebig, "Second law optimization of flat-plate solar air heaters. Part 2: results of optimization and analysis of sensibility to variations of operating conditions," Solar Energy, vol. 41, no. 4, pp. 309-317, 1988.

[19] S. Farahat, F. Sarhaddi, and H. Ajam, "Exergetic optimization of flat plate solar collectors," Renewable Energy, vol. 34, no. 4, pp. 1169-1174, 2009.

[20] H. Ajam, S. Farahat, and F. Sarhaddi, "Exergetic optimization of solar air heaters and comparison with energy analysis," International Journal of Thermodynamics, vol. 8, no. 4, pp. 183190, 2005.

[21] M. J. Kerr and A. Cuevas, "Generalized analysis of the illumination intensity versus open-circuit voltage of solar cells," Solar Energy, vol. 76, no. 1-3, pp. 263-267, 2004.

[22] E. Radziemska and E. Klugmann, "Thermally affected parameters of the current-voltage characteristics of silicon photocell," Energy Conversion and Management, vol. 43, no. 14, pp. 18891900, 2002.

[23] E. E. van Dyk, B. J. Scott, E. L. Meyer, and A. W. R. Leitch, "Temperature dependence of performance of crystalline silicon photovoltaic modules," South African Journal of Science, vol. 96, no. 4, pp. 198-200, 2000.

[24] http://www.gercin.org/renewablepdf/Solar\%20Tariff\%20Order \%201\%20of\%202012.pdf, 2013.

[25] M. Veerachary, T. Senjyu, and K. Uezato, "Voltage-based maximum power point tracking control of PV system," IEEE Transactions on Aerospace and Electronic Systems, vol. 38, no. 1, pp. 262-270, 2002.

[26] M. Veerachary and K. S. Shinoy, "V2-based power tracking for nonlinear PV sources," IEE Proceedings-Electric Power Applications, vol. 152, no. 5, pp. 1263-1270, 2005.

[27] I. S. Kim and M. J. Youn, "Variable-structure observer for solar array current estimation in a photovoltaic power-generation system," IEE Proceedings-Electric Power Applications, vol. 152, no. 4, pp. 953-959, 2005.

[28] I. S. Kim, M. B. Kim, and M. J. Youn, "New maximum power point tracker using sliding-mode observer for estimation of solar array current in the grid-connected photovoltaic system," IEEE Transactions on Industrial Electronics, vol. 53, no. 4, pp. 1027-1035, 2006.

[29] H. L. Tsai, C. S. Tu, and Y. J. Su, "Development of generalized photovoltaic model using MATLAB/SIMULINK," in Proceedings of the World Congress on Engineering and Computer Science, San Francisco, NC, USA, October 2008.

[30] J. C. Thongpron, K. Kirtikara, and C. Jivacate, "A method for the determination of dynamic resistance of photovoltaic modules under illumination," Solar Energy Materials and Solar Cells, vol. 90, no. 18-19, pp. 3078-3084, 2006.

[31] J. C. Wang, J. C. Shieh, Y. L. Su et al., "A novel method for the determination of dynamic resistance for photovoltaic modules," Energy, vol. 36, no. 10, pp. 5968-5974, 2011.

[32] S. Dubey, G. S. Sandhu, and G. N. Tiwari, "Analytical expression for electrical efficiency of PV/T hybrid air collector," Applied Energy, vol. 86, no. 5, pp. 697-705, 2009.

[33] S. Kumar, P. K. Singh, G. S. Chilana, and S. R. Dhariwal, "Generation and recombination lifetime measurement in silicon wafers using impedance spectroscopy," Semiconductor Science and Technology, vol. 24, no. 9, Article ID 095001, pp. 1-8, 2009.

[34] J. Millman and C. C. Halkias, Integrated Electronics, McGrawHill, New York, NY, USA, 1972.
[35] S. Kumar, P. K. Singh, and G. S. Chilana, "Study of silicon solar cell at different intensities of illumination and wavelengths using impedance spectroscopy," Solar Energy Materials and Solar Cells, vol. 93, no. 10, pp. 1881-1884, 2009.

[36] S. Kumar, V. Sareen, N. Batra, and P. K. Singh, "Study of C-V characteristics in thin n+-p-p+ silicon solar cells and induced junction n-p-p+ cell structures," Solar Energy Materials and Solar Cells, vol. 94, no. 9, pp. 1469-1472, 2010.

[37] I. Mora-Seró, G. Garcia-Belmonte, P. P. Boix, M. A. Vázquez, and J. Bisquert, "Impedance spectroscopy characterisation of highly efficient silicon solar cells under different light illumination intensities," Energy and Environmental Science, vol. 2, no. 6, pp. 678-686, 2009.

[38] F. Sarhaddi, S. Farahat, H. Ajam, and A. Behzadmehr, "Exergetic optimization of a solar photovoltaic array," Journal of Thermodynamics, vol. 2009, Article ID 313561, 11 pages, 2009.

[39] S. M. Sze, Physics of Semiconductor Devices, Wiley, New York, NY, USA, 2nd edition, 1981. 

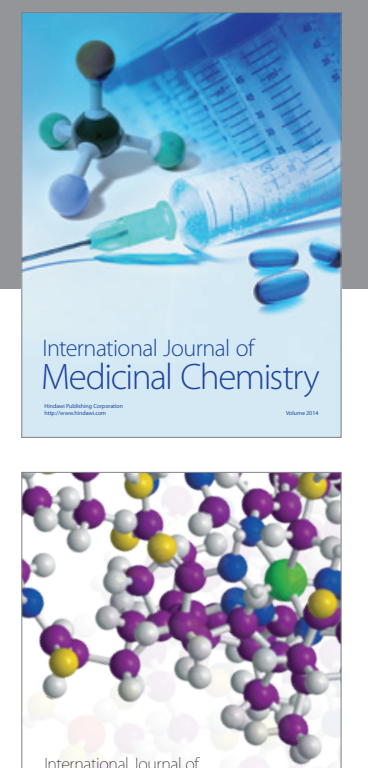

\section{Carbohydrate} Chemistry

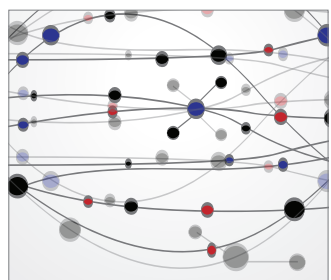

The Scientific World Journal
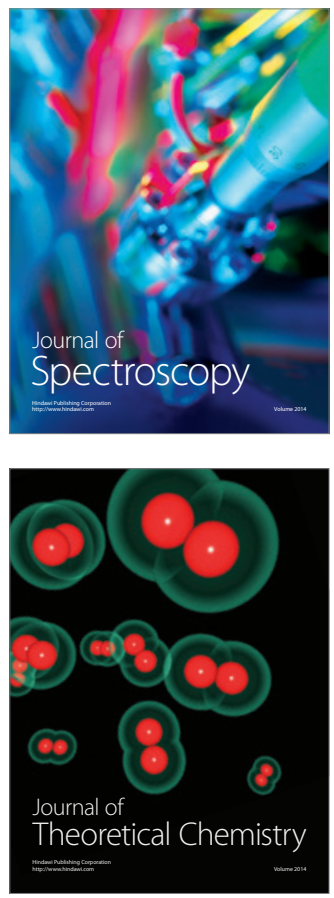
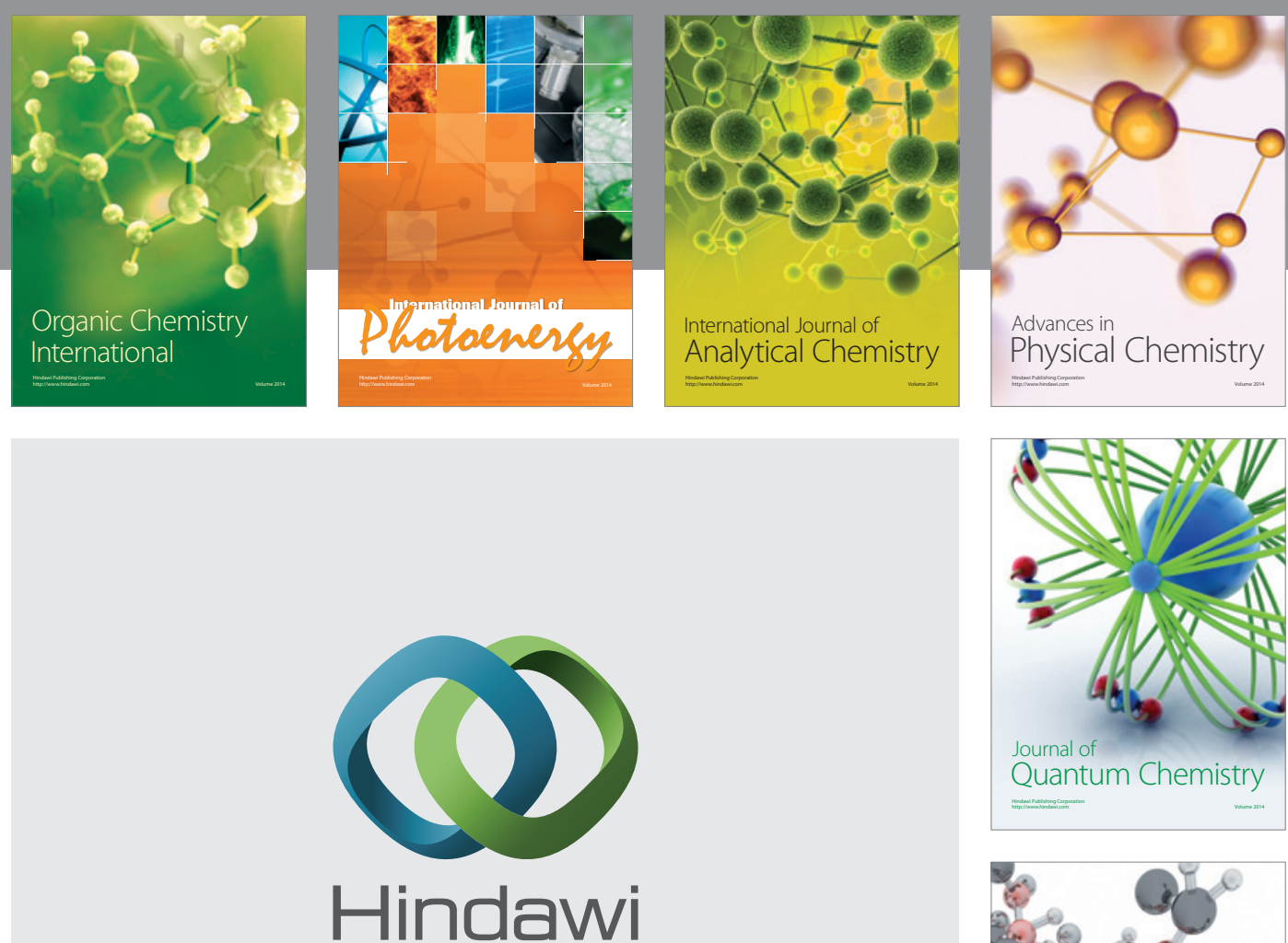

Submit your manuscripts at

http://www.hindawi.com

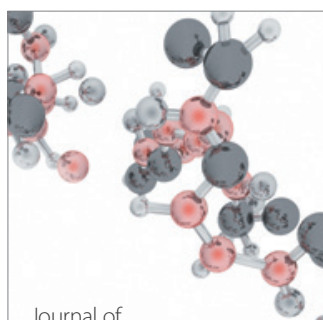

Analytical Methods

in Chemistry

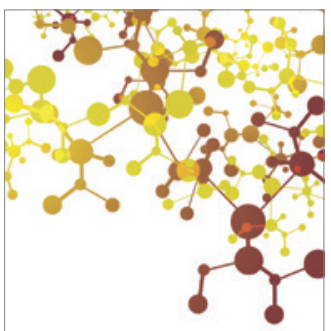

Journal of

Applied Chemistry

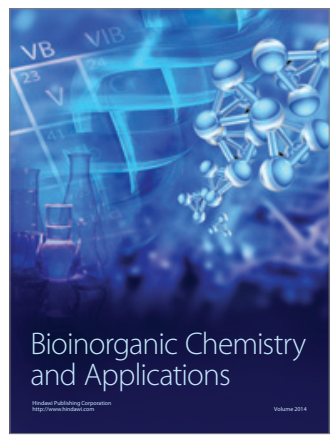

Inorganic Chemistry
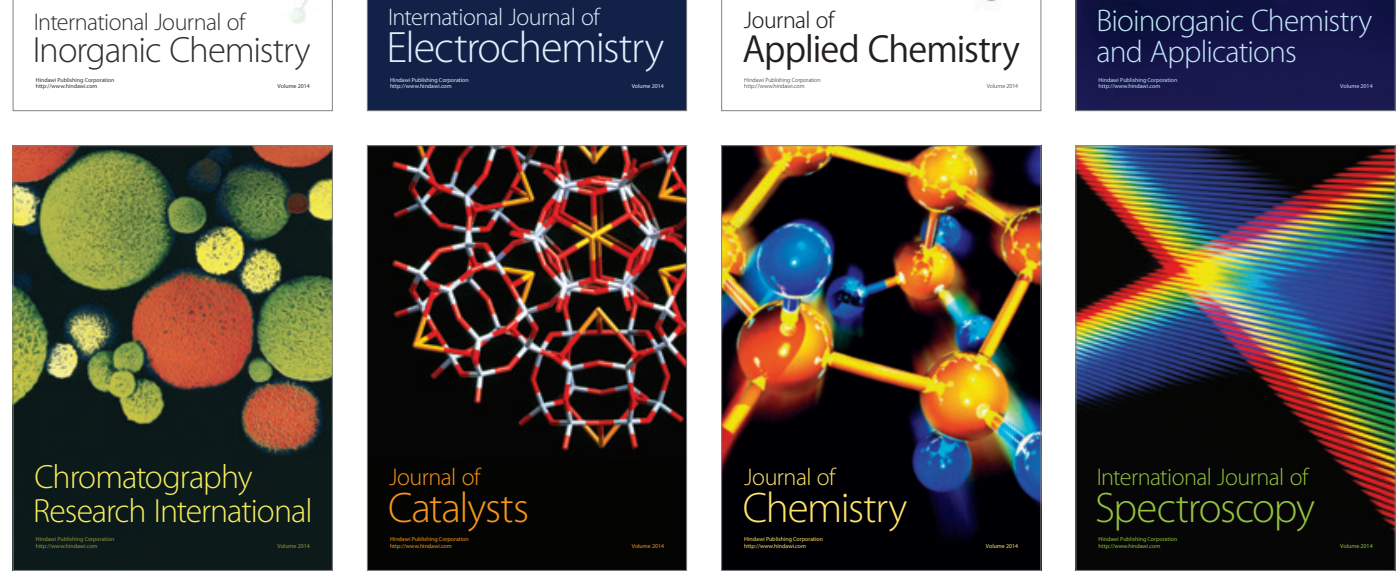